\title{
Pemilihan Jenis Musik Dalam Peribadatan Kristen
}

\author{
${ }^{1}$ Ferry Purnama, ${ }^{2}$ Yanto Paulus Hermanto, ${ }^{3}$ Krisna Firnando
}

\author{
Sekolah Tinggi Teologi Kharisma Bandung \\ ${ }^{1}$ bbm.purnamaferry@gmail.com, ${ }^{2}$ yantopaulush@gmail.com, ${ }^{3}$ krisnafernando75@gmail.com
}

\begin{abstract}
Abstrak
Musik dapat diartikan sebagai sebuah bahasa, yang dapat menyampaikan pesan-pesan tertentu kepada pendengarnya. Musik dapat dipergunakan untuk hal-hal positif, namun juga dapat dipergunakan untuk hal-hal yang negatif. Bahkan ada sebuah ungkapan yang mengatakan "musik adalah bahasa universal", sebab memang musik bersifat netral. Dalam gereja sendiri, musik telah dipergunakan sejak jaman Alkitab dituliskan. Dalam perkembangannya, musik dalam ibadah semakin bervariasi, dan semakin kompleks. Hal tersebut dipengaruhi oleh berkembangnya teknologi, dan semakin kreatifnya para musisi pada jaman ini. Di kalangan Kristen sendiri, ada pertentangan berkenaan dengan penggunaan musik yang bervariasi dalam ibadah. Tidak hanya itu, adanya penggunaan musik-musik tertentu untuk menyembah Setan, memberikan konotasi negative bagi penggunaan musik tertentu dalam ibadah Kristen. Stereotip yang melekat pada suatu jenis musik tersebut perlu disikapi dengan benar. Karenanya gereja perlu mengetahui aspekaspek yang menjadi pertimbangan dalam memilih musik untuk peribadatannya.
\end{abstract}

Kata kunci: Musik, genre, konotasi, ibadah, gereja

\begin{abstract}
Music can be interpreted as a language, which can convey certain messages to the listeners. Music can be used for positive things, but it can also be used for negative things. There is even an expression that says "music is a universal language", because music is neutral. Within the church itself, music has been used since the time the Bible was written. During its development, music in worship is increasingly varied and more complex. This is influenced by the development of technology, and the increasingly creative musicians of this era. Among Christians themselves, there are conflicts regarding the use of various music in worship. Not only that, the use of certain music to worship Satan has a negative connotation for the use of certain music in Christian worship. The stereotype attached to a type of music needs to be addressed properly. Therefore the church needs to know the aspects that are considered in choosing music for its worship.
\end{abstract}

Keywords: Music, genre, connotation, worship, church

\section{Pendahuluan}

Secara umum, musik dibedakan menjadi 2, yaitu berdasarkan penggunaannya, dan berdasarkan fungsinya. Dalam penggunaannya, musik dapat dipergunakan untuk berbagai terapi. Efek rileks yang dihasilkan dari musikmusik yang lembut, dapat membuat fikiran dan perasaan menjadi tenang. Dan musik juga dipercaya dapat memberikan dampak emosional. Proses mendengarkan musik merupakan salah satu bentuk komunikasi afektif dan memberikan pengalaman emosional $^{1}$. Musik juga secara bebas dan

\footnotetext{
${ }^{1}$ Siti Fitroh, Siti Fadjryana Fitroh, and Siti Mulifatin Khasanah, "Musik Sebagai Stimulus Pada Kecerdasan Emosi Anak (Studi Kasus
} 
luas digunakan oleh berbagai kalangan untuk menyampaikan pesan. Tidak terkecuali aliran Iluminati. Ada beberapa penyanyi dunia yang terang-terangan menyampaikan pesan lluminati dalam setiap video clip yang mereka buat. Berikut adalah contoh artis-artis yang dimaksud.

Tabel 2 Data Video Klip dengan Unsur Simbol Illuminat

\begin{tabular}{ccc}
\hline No & Penyanyi & Judul Lagu \\
& & \\
\hline 1 & Britney Spears & Hold It Againts Me \\
\hline 2 & Eminem Ft. Rihanna & The Monster \\
\hline 3 & Lady Gaga & Bad Romance \\
\hline 4 & Lady Gaga & Judas \\
\hline 5 & Lil & Wayne Ft. Drake, \\
\hline & Future & Love Me \\
\hline 6 & Rihana & Umbrella \\
\hline 7 & Will I. Am Ft. & Scream \& Shou \\
\hline 8 & Britney & Dark Horse \\
\hline 9 & Katy Parry & Alejandro \\
\hline 10 & Lady Gaga & Die Young \\
\hline
\end{tabular}

Dari berbagai macam kegunaan dan fungsi tersebut, membuat musikmusik tertentu dianggap memiliki dampak yang negatif. Sebagai contoh misalnya musik dangdut koplo. Dangdut koplo diidentikkan dengan goyangan-goyangan yang heboh, dan atraktif. Sebab memang ada orang yang mempergunakan musik dangdut yang dibumbui dengan goyangan-goyangan heboh. Contoh lain

TK A Di Kelompok Bermain Kasih Ibu)," Jurnal PG-PAUD Trunojoyo : Jurnal Pendidikan dan Pembelajaran Anak Usia Dini (2016). misalnya musik Reggae. Musik ini berlatar berasal dari Jamaika, dan identik dengan narkoba, sehingga identitas tersebut membuat aliran musik ini mendapat pandangan yang negatif. Beberapa aliran musik tertentu memang dianggap menjadi identitas atau ciri dari suatu kelompok tertentu. Seseorang bisa saja dipengaruhi oleh stereotipe dari jenis musik tertentu yang mereka dengar. Stereotipe ini bisa saja membiaskan penilaian seseorang terhadap suatu jenis musik ${ }^{2}$.

Penggunaan musik dalam ibadah tidak dapat dilepaskan sejarah yang melatarbelakanginya. Sebagai contoh adalah gereja HKBP, yang pada awalnya bernama Gereja Mission Batak (GBM). Para missionarisnya memperkenalkan Kekristenan dengan berkhotbah dan juga dengan bermusik. Alat musik yang dipergunakan pada waktu adalah Organ, atau orang-orang pada waktu itu menyebutnya Poti Marende, dan juga alat musik tiup. Berjalannya waktu alat musik ini sudah mulai ditinggalkan, berganti dengan alat musik Organ Elekterik, dan juga alat musik etnik, seperti Gondang. Dan semakin berkembangnya dunia musik, alat Musik yang dipergunakan semakin variatif, selain Organ gereja, gereja HKBP juga mempergunakan Piano, Biola, gitar, saxophone, Terompet, taganing, sulim. Alat-alat musik tersebut dipergunakan untuk tujuan membawa

\footnotetext{
${ }^{2}$ Rinanda Rizky Amalia Shaleha1, "Do Re Mi: Psikologi, Musik, Dan Budaya" Vol. 27, N (2019): 47.
} 
suasana ibadah menjadi khusuk. $^{3}$

Sehingga musik-musik keras seperti Rock, Funk, Disco masih tabu untuk dimainkan di gereja. Di Indonesia sendiri ada banyak gereja yang berpandangan seperti itu, khususnya untuk Gereja Injili. Hal ini sangat berbeda dengan gereja-gereja Pentakosta atau Kharismatik, seperti GBI, JPCC, GIA, dan aliran Pentakosta Kharismatik lainnya, yang lebih variatif dan luas dalam penggunaan musik ibadahnya.

Oleh sebab itu, penelitian ini bertujuan agar gereja bisa memahami jenis musik mana saja yang dapat digunakan, dan bagaimana menyesuaikan dengan konteks gereja masing-masing.

\section{Metode penelitian}

Penelitian ini menggunakan metode kualitatif, dimana penulis mengumpulkan berbagai sumber, baik itu buku maupun jurnal-jurnal yang berhubungan dengan materi yang sedang dibahas.

Selain itu penulis juga
membandingkan pandangan gereja
tertentu tentang penggunaan musik dalam ibadahnya, serta mencari karakteristik dari jenis-jenis musik tertentu, sehingga didapatkan pertimbangan yang logis untuk menentukan jenis musik yang akan dipakai dalam ibadah.

\footnotetext{
${ }^{3}$ Naomi Pasaribu, "MUSIK GEREJA DARI SUDUT PANDANG THEOLOGIA HKBP," no. 1952 (1964): 1-11.
}

\section{Hasil dan Pembahasan}

\section{Pengertian Musik Secara Umum}

Beberapa sumber yang ada memberikan beberapa definisi tentang musik, berikut adalah definisi yang ada: pertama, Musik adalah ilmu atau seni yang menyusun suara atau nada dalam susunan, kombinasi, dan hubungan temporal dengan tujuan menghasilkan komposisi (suara) yang menyatu dan saling berkesinambungan ${ }^{4}$. Kedua, musik dapat diartikan sebuah suara atau nada yang disusun demikian rupa sehingga di dalamnya terdapat unsur-unsur seperti irama, lagu, dan keharmonisan. ${ }^{5}$ Ketiga, musik diartikan sebagai ilmu pengetahuan tentang penggabungan dari vocal (suara manusia) atau alat musik (instrument), atau nada dalam berbagai macam melodi, ritme/irama, harmoni, dan timbre atau warna suara, khususnya untuk membuat sebuah komposisi yang memiliki susunan yang utuh dan dapat mengekspresikan emosi tertentu ${ }^{6}$. Keempat, musik adalah seni menggabungkan suara dengan menggunakan berbagai macam instrumen musik atau penyanyi untuk menghasilkan bentuk irama, melodi, dan harmoni yang dimaksudkan untuk mengekspresikan pikiran atau perasaan dan untuk

\footnotetext{
${ }^{4}$ Pusat Pembinaan Dan Pengembangan Bahasa Kamus Besar Bahasa Indonesia (Jakarta: Departemen Pendidikan Dan Kebudayaan., n.d.).

${ }^{5}$ Ibid

${ }^{6}$ College Edition, Webster's New World Dictionary of The American Language (Cleveland and New York: The World Publishing Company., 1960).
} 
mempengaruhi emosi ${ }^{7}$. Kelima, musik adalah ekspresi suara yang berirama untuk menyatakan pikiran dan emosi ${ }^{8}$. Keenam, musik adalah bahasa emosi yang disusun dari nada-nada (berbagai warna nada) yang membentuk kesatuan yang menghasilkan ciri khas pada suara, melodi atau lagu, harmoni (nada-nada yang berhubungan yang dibunyikan bersama-sama), dan ritme atau irama. ${ }^{9}$

Hal tersebut di atas memberikan definisi yang memiliki kesamaan, yaitu adanya suara yang dihasilkan. Suara tersebut dapat membentuk harmoni, nada, irama, yang bersifat netral. Semua dapat menggunakan musik untuk tujuannya masing-masing.

Secara khusus, musik dapat dikelompokkan berdasarkan kegunaannya. Seperti yang telah disinggung di bagian sebelumnya, musik juga dapat berguna sebagai relaksasi, yang kemudian diidentifikasikan sebagai musik relaksasi. Musik juga dapat dihubungkan dengan istilah gerejawi, sehingga diidentifikasi menjadi musik gereja.

Terbukti bahwa penggunaan musik dalam ibadah adalah sesuatu yang sah, sesuai dengan sifat musik itu sendiri yang bersifat netral, maka musik juga dapat

\footnotetext{
${ }^{7}$ Bay Books., The Great Family Encyclopedia Dictionary. (Oxford University Press., 1986).

${ }^{8}$ Lane Miller, Madeleine, S., dan Miller, J., Harper's Bible Dictionary (New York: Harper \& Row Publisher., 1973).

${ }^{9}$ D Berkley, James, Leadership Handbooks of Practical Theology (Vol. 1). (Michigan: Baker Book House., n.d.).
}

dipergunakan sebagai sarana pemujaan kepada Allah.

\section{Pengertian Musik Gereja}

Secara sederhana musik gerejawi dipahami sebagai semua musik entah itu merupakan musik vocal ataupun instrumentalia yang menjadi bagian dari liturgi peribadatan ${ }^{10}$. Sedangkan sebagai sebuah karya seni, musik gerejawi memiliki arti sebagai sebuah nada dalam bentuk vocal (suara manusia), atau juga bunyi dari sebuah instrument atau alat musik yang disusun dengan begitu rupa sehingga menghasilkan unsur-unsur seperti irama, dinamika, melodi, dan harmoni yang saling berkesinambungan yang merupakan ekspresi dari sang composer, yang kemudian komposisi tersebut mampu mempengaruhi orang yang mendengarkan untuk merubah sikap dan perilakunya menjadi memuliakan Tuhan, dan juga untuk meresponi apa yang Tuhan sudah lakukan dalam kehidupan manusia. ${ }^{11}$

Dari definisi ini, kita melihat ada dua unsur yang menjadi sumber terjadinya suara, yang pertama adalah manusia itu sendiri, yang menghasilkan bunyi vocal, di mana di dalamnya terdapat nada, dan juga kata-kata secara bersamaan. Lalu yang kedua adalah instrumental, yaitu alat musik yang dipergunakan untuk

\footnotetext{
${ }^{10}$ Agastya Rama Listya, "Kontekstualisasi Musik Gerejawi : Sebuah Keniscayaan" 2 (n.d.).

11 Jacky Supit, Musik-Gerejawi, n.d.
} 
menghasilkan suara. Dalam peristiwa di Alkitab kita melihat ketika raja Saul dihantui oleh roh jahat, Daud menghibur dengan memainkan kecapi (1 Sam. 16:16). Kemudian raja Saul pun merasa tenang dan roh jahat itupun menjadi pergi meninggalkan dia (1 Sam. 16:23). Musik yang dimainkan oleh Daud memiliki kuasa sebab Allah memperkenan Daud. Jadi musik menjadi di sini musik menjadi sarana Allah menyatakan kuasa-Nya untuk mengusir roh jahat. Saat ini instrument musik telah mengalami perkembangan yang begitu signifikan. Perkembangan tekhnologi turun mempengaruhi keaneka ragaman istrumen musik, yang akhir-akhir ini semakin variatif.

Definisi musik dalam unsur vocal juga telah mengalami perkembangan. Kita melihat terjadi perkembangan perlakuan terhadap cara menyanyi jemaat dalam ibadah. Pada awalnya, nyanyian atau pujian jemaat dalam suatu peribadatan hanyalah menyanyikan Mazmur ${ }^{12}$ saja, kemudian berkembang dengan adanya himne. Himne adalah nyanyian yang memiliki bait dengan syair baru, yang isinya bukan dari kitab suci. Tokoh musik yang mengembangkan pujian Himne ini adalah Ambrosius (333-397) dan

\footnotetext{
${ }^{12}$ Dr. J.L.Ch.Abineno, Unsur-Unsur Liturgia Yang Dipakai Oleh Gereja-Gereja Di Indonesia (Jakarta: BPK Gunung Mulia, 2005).
}

Gregorius Agung (590-604) ${ }^{13}$. Ambrosius sendiri dianggap sebagai Bapak Himne Katholik karena karya-karyanya sangat mempengaruhi perkembangan musik dikemudian ${ }^{14}$. Kedua unsur tadi (vocal dan instrument) dalam musik gereja biasanya menjadi satu kesatuan yang menjadi salah satu sarana untuk memuji Tuhan. kata "memuji" sendiri memiliki arti suatu ungkapan perasaan kagum kepada "seseorang" atau kepada suatu objek yang begitu tulus, yang membuat seseorang mengelu-elukan, menghargai, dan menyanjung "seseorang" atau objek yang kita puji. ${ }^{15}$

Jadi dalam musik gereja, musik dipakai menjadi pujian kepada Tuhan sebagai ungkapan perasaan kagum, perasaan syukur, dan juga ketaatan. Kedua unsur tadi (vocal dan instrument) bisa berjalan sendiri-sendiri ataupun berjalan bersama.

\section{Dasar Teologis Penggunaan Musik Dalam Ibadah \\ Musik sebagai bagian dari ibadah} telah dimulaikan di Sorga sampai ke bumi ini. Menurut catatan sejarah Kitab Suci, musik telah memainkan peran yang amat

\footnotetext{
${ }^{13}$ Susan T. Sommer et al., "The New Grove Dictionary of Music and Musicians," Notes (1981).

${ }^{14}$ Albert Seay, Music in the Medieval World (, New Jersey: Englewood Cliffs, 1975).

${ }^{15}$ M. Div Rohani Siahaan, "104125-MemujiDengan-Nyanyian-Dalam-Ibadah-Jema6e52b856.Pdf," n.d.
} 
penting dalam peribadatan umat Kristen ${ }^{16}$. Dalam perjalanan bangsa Israel, mereka sudah tidak asing dengan yang namanya ibadah. Sejak keluar dari tanah Mesir, mereka telah biasa melakukannya.

Ada beberapa peristiwa dalam Alkitab, yang menunjukkan peran penting musik dalam pujian penyembahan manusia kepada Allah, salah satunya adalah pujian penyembahan Musa. Dalam kitab Keluaran 15:1-21 memberikan prinsip-prinsip penting persembahan musik dalam ibadah kepada Tuhan. Isi kitab ini merupakan nyanyian Musa bersama-sama dengan seluruh bangsa Israel. Dari nyanyian Musa tersebut, terdapat tiga prinsip penting tentang persembahan musik gerejawi kepada Tuhan. Pertama, Musa mengajak seluruh bangsa Israel untuk menaikkan pujian tentang Tuhan yang sangat agung dan mulia. Kedua, musiknya menyuarakan tentang karya penyelamatan yang dilakukan Tuhan, dan telah membebaskan mereka dari tangan para musuh. Ketiga, musiknya menyuarakan tentang atribut yang melekat pada Allah: Allah disebut sebagai pribadi yang Agung dan Mulia, pribadi yang kudus dan sangat mengagumkan, dan juga Dia adalah Allah yang memiliki kasih yang tidak terhingga. Musa tentu memiliki motivasi yang mendorong dia untuk menaikkan nyanyian pujian kepada Allah, dan juga mengajak

\footnotetext{
${ }^{16}$ M.Th. Mawene, Gereja Yang Menyanyi (Yogyakarta: ANDI Offset, 2004).
}

umat Israel untuk melakukan hal yang sama. Dalam Kitab Keluaran 15:1-21 setidaknya ada tiga hal nampak berkaitan dengan motivasi tersebut. Pertama, mereka memuji Allah karena keberadaanNya sebagai mana Dia telah ada. Kedua, karena apa yang telah Allah lakukan. Mereka ingin menaikkan syukur atas perbuatan Allah yang telah mereka nikmati. Ketiga, mereka memuji Allah karena hubungan yang istimewa dengan Allah. ${ }^{17}$

Berdasarkan Keluaran 15:1-21 memberikan suatu prinsip penting mengenai aspek dari musik gerejawi; (1) Mengajarkan tentang Tuhan, yang adalah Allah yang benar; (2) menyatakan iman kepada Allah yang diajarkan kepada orang lain; (3) menyaksikan perbuatan Tuhan, yang diimaninya, kepada sesama. Musik gerejawi harus memenuhi ketiga hal di atas. ${ }^{18}$

Inilah yang menjadi pembeda antara musik gereja dengan musik yang lainnya. Pesan yang disampaikan dan motivasi yang mendasari musik tersebut harus berisi tentang Tuhan, tentang iman Kristen, dan tentang perbuatan Allah kepada manusia. Alkitab mengatakan bahwa musik dapat digunakan ketika sedang melakukan perayaan tertentu seperti contoh nyanyian Miriam pada Kitab

\footnotetext{
17 Jacky Supit, "Musik-Gerejawi," n.d.

${ }^{18}$ Ibid 5
} 
Keluaran 15:20-21 ${ }^{19}$. Dikatakan dalam ayat tersebut "Lalu Miryam, nabiah itu, saudara perempuan Harun, mengambil rebana di tangannya, dan tampillah semua perempuan mengikutinya memukul rebana serta menari-nari. Dan menyanyilah Miryam memimpin mereka: "Menyanyilah bagi TUHAN, sebab la tinggi luhur; kuda dan penunggangnya dilemparkan-Nya ke dalam laut. ${ }^{20}$ "(Kel.15:20-21). Perayaan lain juga dilakukan oleh orang Israel, yang merayakan kemenangan Daud atas orang Filistin seperti yang tertulis dalam 1 Samuel 18:7.

Hal tersebut spontan dilakukan oleh perempuan Israel sebagai ungkapan kegembiraan mereka. Mereka juga mempergunakan alat-alat musik untuk menambah suasana semarak dalam perayaan tersebut.

Dalam peritiwa lainnya, saat peristiwa pentahbisan tembok Yerusalem, musik juga dipakai untuk perayaan yang megah. Seperti yang tercatat dalam kitab Nehemia 12:27, dimana orang-orang Lewi dari berbagai tempat dipanggil ke Yerusalem, dan di sana diadakan suatu pentahbisan yang begitu meriah dengan ucapan syukur. Ada juga berbagai alat musik yang dipakai Pada pentahbisan tembok Yerusalem orangorang Lewi dipanggil dari segala tempat

\footnotetext{
${ }^{19}$ A. Simanjuntak, Tafsiran Alkitab Masa Kini

1, Kejadian-Ester (Jakarta: Yayasan

Komunikasi Bina Kasih, 2007).

${ }^{20}$ Alkitab Terjemahan Baru
}

mereka dan dibawa ke Yerusalem untuk mengadakan pentahbisan yang meriah dengan ucapan syukur, di ketika itu juga dibawakan nyanyian kidung, dengan diiringi ceracap, gambus dan kecapi (Neh. $12: 27) .^{21}$

Kita melihat dalam Kitab Nehemia, bahwa ada orang-orang khusus yang dipercaya untuk menjalankan tugas tersebut. Orang-orang tersebut adalah orang yang harus menjaga hidup mereka dari kecemaran, sehingga apa yang mereka lakukan diperkenan oleh Tuhan. Dalam perayaan ini, alat-alat musik yang digunakan pada waktu itu adalah alat musik yang populer pada masa itu. Tidak semua orang dapat memainkannya, dan tidak semua orang memilikinya. Artinya, dalam peribadatan kepada Tuhan, alat musik apapun dapat dipergunakan, untuk memuliakan Tuhan, sejauh tidak menjadi batu sandungan bagi jemaat, atau mengalihkan jemaat dari tujuan adanya musik tersebut

\section{Jenis Musik Yang Umum Digunakan Oleh Gereja-Gereja Di Indonesia}

Dunia musik saat telah mengalami perkembangan yang signifikan. Perkembangan teknologi berperan besar dalam perkembangan tersebut. Ada berbagai jenis musik yang semakin atraktif, karena hadirnya alat-alat musik yang semakin canggih. Sebagai contoh alat musik seperti synthesizer, DJ, dan

21 ibid 
lain sebagainya. Perkembangan tersebut juga telah masuk ke dalam gereja-gereja yang menonjolkan pujian penyembahan, seperti gereja-gereja Kharismatik. Irama musik cepat, seperti irama Rock, Disco, Funk, Latin, bahkan irama Etnik dari berbagai daerah di Indonesia juga seringkali dipakai dalam ibadah, seperti misalnya etnik Batak, etnik Jawa, etnik Tionghoa, dan berbagai irama etnik lainnya. Bahkan dibeberapa gereja besar di Indonesia juga menggunakan Electronic Dance Music (EDM) dalam ibadahnya. Ada juga musik lambat seperti Ballad, 8 beat, Slow Rock, Waltz, dan lain sebagainya, yang biasanya dipergunakan untuk mengiringi lagu-lagu lambat. Jenis musik di atas adalah jenis musik popular yang saat ini menghiasi keberagaman musik rohani di Indonesia. Terdapat begitu banyak pilihan jenis musik yang dapat dipakai dalam ibadah. Semuanya itu harus memiliki pertimbangan-pertimbangan tertentu, sehingga pemilihan irama tersebut tidak menjadi batu sandungan bagi jemaat. Jangan sampai jemaat justru terfokus pada musiknya, daripada penyembahan kepada Tuhan.

Perkembangan tersebut harus dibarengi dengan pemahaman yang benar tentang musik, sehingga gereja mengetahui aspek-aspek apa saja yang menjadi pertimbangan dalam memilih jenis musik dalam ibadah.

\section{Kriteria Pemilihan Jenis Musik Dalam lbadah}

Musik merupakan hasil dari sebuah pikiran, maka dari itu elemen bunyi dari getaran berupa frekuensi, amplitude, dan durasi akan diterima menjadi sebuah musik jika dapat diubah secara neurologis dan diterjemahkan melalui otak sehingga menjadi sebuah pitch (nada-harmoni), timbre (warna suara), dinamika (keras-lembut), dan tempo (cepat-lambat). ${ }^{22}$ Musik dapat mempengaruhi suasana hati, atau bahkan perilaku seseorang. Musik dapat mempengaruhi seseorang menjadi marah, sedih, ataupun bersemangat. Sebuah studi yang dilakukan oleh Zentner, M., Grandjean \& Scherer menunjukkan bahwa, musik Klasik dan Jazz berkaitan dengan perasaan longing, amazement, spirituality, dan peacefulness. Lalu kemudian musik techno dan juga musik Latin Amerika berkaitan dengan perasaan excited, active, energetic, agitated, dan fiery. Sedangkan musik rock atau musik pop berkaitan dengan perasaan aggressive, angry, irritated, enraged, dan revolted. ${ }^{23}$

Setiap jenis musik memiliki karakteristik dan keunikan masing-masing. Oleh karenanya dalam setiap peribadatan

\footnotetext{
${ }^{22}$ Djohan., Psikologi Musik. (Yogyakarta: Best Publisher., 2009).

${ }^{23}$ K. R. Zentner, M., Grandjean, D., \& Scherer, Emotions Evoked by the Sound of Music: Characterization, Classification, and Measurement. (the American Psychological Association, 2008).
} 
orang percaya, perlu mempertimbangkan beberapa aspek-aspek sehingga musik dalam ibadah menjadi maksimal.

Aspek yang pertama adalah, berkaitan dengan suasana seperti apakah yang ingin dituju. Lagu-lagu Kristen saat ini sudah sangat beragam. Tema-tema yang diambilpun sangat bervariasi. Ada lagu pujian tentang pengagungan kepada Allah, ucapan syukur, tentang iman, dan juga tentang komitmen pribadi. Berbagai pesan dari tema-tema lagu tersebut akan menjadi maksimal tersampaikan jika suasananya mendukung. Suasana tersebut salah satunya diciptakan melalui pemilihan musik yang tepat, dan pemilihan jenis alat musik yang tepat. Sebagai contoh, untuk lagu-lagu pujian yang membutuhkan penghayatan atau penyembahan yang teduh, jenis musik yang dipilih harus musik-musik lambat, dengan menambahkan suara instrument tertentu seperti String, Pad, Violin, Flute atau yang lainnya, yang berkarakter lembut. Misalnya saja lagu "lingkupiku". Lagu pujian ini merupakan pernyataan iman, bahwa dalam keadaan apapun Tuhan selalu menopang kehidupan orang percaya, sehingga orang percaya dapat selalu tenang. Pujian ini dapat didukung dengan pemilihan musik yang tenang, namun megah. Dan itu dapat terjadi dengan dukungan pemilihan musik dan instrument yang tepat. Hal ini juga berlaku jika lagu yang dinyanyikan bertemakan tentang semangat yang menyala-nyala, atau lagu riang. Seperti misalnya lagu "bangkit, serukan nama Yesus". Lagu pujian ini tentu harus dibangun dengan pemilihan musik yang tegas, dan bersemangat, seperti musik Rock, atau Disco, sehingga spirit lagu tersebut akan semakin maksimal. Namun tidak selalu lagu tentang iman diiringi dengan musik yang lambat, dan tidak selalu juga lagu yang bersemangat harus diiringi dengan musik yang cepat. Hal itu tergantung dari suasana seperti apa yang ingin diciptakan dalam sebuah peribadatan tersebut. Selain itu, pemilihan musik juga harus dibarengi dengan pitch (nada-harmoni), timbre (warna suara), dinamika (keraslembut), sehingga suasana ibadah terbangun dengan begitu indah.

Aspek kedua adalah, berkaitan dengan dampak psikologis yang ditimbulkan. Seperti yang diuraikan di atas, bahwa musik memiliki dampak dalam perilaku, maka ada jenis musikmusik tertentu yang sebaiknya dipertimbangkan untuk dipergunakan dalam ibadah. Seperti misalnya musik Hard Rock, Metal, atau juga musik Dangdut Koplo. Tentu perlu dipertimbangkan juga mengenai budaya yang ada di dalam jemaat, jangan sampai gereja memaksakan musik yang justru menjadi batu sandungan bagi jemaat dalam memuji dan memuliakan nama Tuhan melalui nyanyian.

Kedua aspek di atas perlu menjadi pertimbangan dalam memilih jenis musik, 
agar musik yang dipilih tersebut menjadi kesatuan harmoni yang indah bersama dengan suara seluruh jemaat yang ada.

\section{Kesimpulan}

Allah menciptakan manusia untuk kemuliaan-Nya. Allah akan sangat senang dan dipermuliakan dengan musik yang dipersembahkan oleh umat yang sudah dikuduskan $^{24}$. Hal ini berkaitan dengan para pemain musik itu sendiri, yang harus menjaga hidupnya tetap kudus di hadapan Tuhan. Dengan dasar tersebut di atas, dapat disimpulkan bahwa tujuan musik dalam gereja tidak lain adalah sebagai sarana penyembahan. Musik juga persembahan kepada Allah Yang Agung. Oleh sebab itu musik di dalam gereja harus dipersiapkan dengan baik, sebab kita tidak mungkin mempersembahkan sesuatu yang sembarangan kepada Tuhan. Itu artinya, musik dalam ibadah bukanlah sebuah alunan yang menghipnotis, dan menjadi ajang pertunjukkan. Roma 11:36 menyatakan, "Sebab segala sesuatu adalah dari Dia, dan oleh Dia, dan kepada Dia: Bagi Dialah kemuliaan sampai selama-lamanya!" Musik adalah bagian dari segala sesuatu tersebut, itu artinya Allah yang memberi inspirasi manusia untuk menciptakan musik, dan itu harus dipergunakan untuk

\footnotetext{
${ }^{24}$ Esther Santoso, "Musik Dalam Ibadah," Jurnal Theologia Aletheia 4, no. Maret (2002): $45-51$.
}

memuliakan Tuhan untuk selamalamanya.

Batasan dalam penggunaan musik itu sendiri adalah kembali kepada tujuan utama musik itu dibuat, yaitu fokus dan tujuan utamanya untuk memuliakan Tuhan. Musik sebagai sarana manusia untuk memuji dan menyembah Tuhan. Selain itu menjadi cara menaikkan ucapan syukur kepada Tuhan, dan bukan untuk kepuasan para pemain musik.

Penulis memperhatikan akhir-akhir ini ada gereja-gereja mulai yang menggunakan alat-alat musik yang semakin modern, seperti EDM (Electronic Dance Music), maka gereja dapat melihat respon yang muncul. Apakah hal itu menjadi pendukung dalam jemaat memuji dan menyembah Tuhan, atau justru menjadi penghambat.

\section{Kepustakaan}

Albert Seay. Music in the Medieval World. , New Jersey: Englewood Cliffs, 1975.

Bay Books. The Great Family Encyclopedia Dictionary. Oxford University Press., 1986.

Berkley, James, D. Leadership Handbooks of Practical Theology (Vol. 1). Michigan: Baker Book House., n.d.

College Edition. Webster's New World Dictionary of The American Language. Cleveland and New York: The World Publishing Company., 1960.

Djohan. Psikologi Musik. Yogyakarta: Best Publisher., 2009.

Fitroh, Siti, Siti Fadjryana Fitroh, and Siti 
Mulifatin Khasanah. "Musik Sebagai Stimulus Pada Kecerdasan Emosi Anak (Studi Kasus TK A Di Kelompok Bermain Kasih Ibu)." Jurnal PG-PAUD Trunojoyo: Jurnal Pendidikan dan Pembelajaran Anak Usia Dini (2016).

J.L.Ch.Abineno, Dr. Unsur-Unsur Liturgia Yang Dipakai Oleh Gereja-Gereja Di Indonesia. Jakarta: BPK Gunung Mulia, 2005.

Jacky Supit. Musik-Gerejawi, n.d.

. "Musik-Gerejawi," n.d.

Lestari, Winda Yunita, and Freddy Yusanto. "Simbol Illuminati Dalam Video Klip." ProTVF (2019).

Listya, Agastya Rama. "Kontekstualisasi Musik Gerejawi : Sebuah Keniscayaan" 2 (n.d.).

M.Th. Mawene. Gereja Yang Menyanyi. Yogyakarta: ANDI Offset, 2004.

Miller, Madeleine, S., dan Miller, J., Lane. Harper's Bible Dictionary. New York: Harper \& Row Publisher., 1973.

Naomi Pasaribu. "MUSIK GEREJA DARI SUDUT PANDANG THEOLOGIA HKBP," no. 1952 (1964): 1-11.
Rinanda Rizky Amalia Shaleha1. "Do Re Mi: Psikologi, Musik, Dan Budaya" Vol. 27, N (2019): 47.

Rohani Siahaan, M. Div. "104125-MemujiDengan-Nyanyian-Dalam-IbadahJema-6e52b856.Pdf," n.d.

Santoso, Esther. "Musik Dalam Ibadah." Jurnal Theologia Aletheia 4, no. Maret (2002): 45-51.

Simanjuntak, A. Tafsiran Alkitab Masa Kini 1, Kejadian-Ester. Jakarta: Yayasan Komunikasi Bina Kasih, 2007.

Sommer, Susan T., William Morris, Virgil Thomson, Michael Tilson Thomas, and Stanley Sadie. "The New Grove Dictionary of Music and Musicians." Notes (1981).

Zentner, M., Grandjean, D., \& Scherer, K. R. Emotions Evoked by the Sound of Music: Characterization, Classification, and Measurement. the American Psychological Association, 2008.

Pusat Pembinaan Dan Pengembangan Bahasa Kamus Besar Bahasa Indonesia. Jakarta: Departemen Pendidikan Dan Kebudayaan., n.d. 